Jurnal IImu Fisika dan Pembelajarannya (JIFP), Vol. 2, No.2, Desember 2018, 20-33

\title{
PENGEMBANGAN BUKU SAKU (E-MEDIA) TERMODINAMIKA BERORIENTASI ANDROID
}

\author{
Andi Putra Sairi ${ }^{1}$ \\ ${ }^{1}$ Program Studi Pendidikan Fisika, UIN Raden Fatah Pelambang
}

andiputrasairi uin@radenfatah.ac.id

\begin{abstract}
Abstrak
Completing the teaching material is a task that must be carried out by the lecturer when carrying out pedagogical and pedagogical activities. A good learning tool is an element that must exist and must always be developed in order to improve the quality of learning in universities, such as learning materials. Indeed, the learning medium itself is a tool used to transmit knowledge to students in order to overcome the limitations of the senses, time and space. In addition, the availability of learning materials should also follow the evolution of the science and technology that is developing at this time. On this basis, efforts should be made to develop an educational resource in the form of an effective " pocket book " that will serve as a pedagogical medium for students to overcome the problems they face. Therefore, the purpose of this study is to describe the design, validity, and efficiency of using a thermodynamic paperback for Android. This research is a research and development $(R \& D$ ) with the model used in this development is the development model of the model 4-D (model Four D). These steps are definition, design, development and propagation (desimination). The results showed that the Androidoriented thermodynamic pocket book (e-media) was very valid, very practical and effective for learning activities.
\end{abstract}

Keywords: Andriod, Development, E-Media, Pocket Book, Thermodynamics

\section{PENDAHULUAN}

Fisika merupakan salah satu bagian dari Sains yang diharapkan dapat memberikan konstribusi dalam membangun sumber daya manusia yang berkualitas karena fisika memegang peran penting dalam perkembangan ilmu pengetahuan dan teknologi. Salah satu peran fisika dalam perkembangan ilmu pengetahuan dan teknologi menemukan konsep-konsep dasar tentang alam seperti konsep termodinamika yang menjadi cikal bakal lahirnya produkproduk tekonolgi. Mengingat begitu besarnya peranan fisika dalam menjawab tantangan global dan penunjang kemajuan teknologi, maka dituntut adanya perubahan ke arah yang lebih baik pada proses pembelajaran fisika di perguruan tinggi. Dengan demikian dapat meningkatkan mutu pembelajaran fisika itu sendiri.

Perguruan tinggi secara umum dan program studi secara khusus adalah tempat di mana mahasiswa belajar dan tentu saja sangat berperan dalam membantu agar mahasiswa memiliki softskill dalam belajar. Salah satu mata kuliah di program studi pendidikan fisika adalah Termodinamika. Termodinamika merupakan mata kuliah wajib yang mengkaji tentang keadaan termal suatu benda yang berubah terhadap suatu keadaan dan banyak sekali konsep dan teori-teori fisika yang harus dikuasai olek mahasiswa program studi pendidikan fisika. Namun masih terdapat sebagian mahasiswa yang mengalami kendala dalam perkuliahan dan berimbas pada rendahnya hasil belajar mereka.

Berdasarkan hasil tanya jawab, mahasiswa selalu mengeluhkan dalam memahami konsep, kurang terampil dalam menejemen waktu, kurang mampu menyelesaikan soal-soal. Mengingat urgennya permasalahan ini maka tugas pokok pendidik harus dioptimal yaitu sebagai fasilitator. Oleh karena itu menyediakan semua kebutuhan perkuliahan menjadi tugas pokok pendidik dalam hal ini adalah dosen yang kemudian disebut sebagai fasilitator untuk semua mata kuliah. Selain itu, ketersediaan media belajar juga dirasa kurang lengkap di program studi maka diharapakan adanya pengembangan 
suatu perangkat pembelajaran yang efektif digunakan di mata kuliah termodinamika.

Perangkat pembelajaran yang baik merupakan bagian yang harus ada dan senantiasa dikembangkan dalam upaya meningkatkan kualitas pembelajaran di perguruan tinggi seperti media pembelajaran. Hal ini dikarenakan media pembelajaran itu sendiri adalah alat yang digunakan untuk menyampaikan ilmu pengetahuan kepada mahasiswa dengan tujuan mengatasi keterbatasan indera, ruang dan waktu. Tidak hanya itu, ketersediaan media pembelajaran juga seyogyanya mengikuti perkembangan ilmu pengetahuan dan teknologi yang sedang berkembang pada saat itu. Atas dasar ini, perlu adanya upaya dalam mengembang suatu media pembelajaran dalam bentuk "Buku Saku" berorientasi android yang efektif untuk dijadikan sebagai salah satu bahan ajar yang dimiliki mahasiswa sebagai upaya mengatasi permasalahan yang mereka hadapi. Kelebihan dari aplikasi buku saku digital berbasis android yaitu mudah digunakan dalam pengoperasianya, praktis penggunanya serta tidak terlalu banyak memakan ruang dalam sistem untuk menginstal aplikasi ini (Ainul Yaqin. 2017).

Tujuan dari penelitian ini yaitu untuk mendeskripsikan desain, mendeskripsikan tingkat validitas, dan mengetahui tingkat keefektifan penggunaan buku saku termodinamika berorientasi android.

\section{METODE PENELITIAN}

Jenis penelitian yang dilakukan adalah penelitian dan pengembangan (Research and Development). Penelitian dan pengembangan merupakan sutau pilihan metode penelitian lain yang digunakan untuk menghasilkan produk tertentu dan menguji keefektifan produk tersebut (Sugiono. 2010). Jadi, berdasarkan dengan namanya $R \& D$ adalah suatu kegiatan penelitian yang dimulai dengan research kemudian melakuakan kegiatan development (pengembangan) (Adnan. 2009). Kegiatan research bertujuan untuk menggali beberapa informasi tentang kebutuhan-kebutuhan pengguna (needs assessment) sedangkan development dilakukan sebagai upaya untuk dapat menghasilkan suatu perangkat pembelajaran. Proses pengembangan suatu perangkat memerlukan banyak kegiatan seperti pengumpulan data dan mengaanalisis data. Tahap menganalisis data termasuk di dalamnya tahap proses validasi ahli dan pada tahap validasi empiris. Sedangkan nama development mengacu pada produk yang dihasilkan yaitu berupa perangkat pembelajaran.

Berdasarkan permasalahan penelitian yang telah dikemukakan sebelumnya, penelitian ini merupakan penelitian pengembangan (Research and Development) karena dalam penelitian ini akan dikembangkan buku saku elektronik berorientasi android. Model yang digunakan dalam pengembangan ini adalah model pengembangan 4-D Model (Four D Model). Tahap-tahap tersebut adalah pendefenisian (define), perancangan (design), pengembangan (development), dan penyebaran (dessiminate) (Trianto 2009).

A. Prosedur Pengembangan

1. Tahap Pendefinisian (Define)

Tahap pendefinisian merupakan tahap awal yang dilakukan dalam kegiatan penelitian dan pengembangan. Kegiatan yang dilakukan pada tahap ini meliputi kegiatan analisis kurikulum, analisis konsep, analisis kebutuhan, dan analisis mahasiswa.

a. Analisis kurikulum

Kurikulum yang digunakan dalam mata kuliah Termodinamika di Program Studi Pendidikan Fisika UIN Raden Fatah Palembang adalah Kerangka Kualifikasi Nasional Indonesia (KKNI). Oleh sebab itu kegiatan ini dimulai dengan menganalisis kurikulum yang dimiliki prodi sehingga kemudian didapatkan CP Prodi dan CP mata 
kuliah. Hal ini dilakukan sebagai upaya agar mahasiswa benar-benar mencapai tujuan pembelajaran diakhir perkuliahan.

\section{b. Analisis Konsep}

Tahap ini dilakukan untuk menganalisis materi ataupun konsep-konsep penting yang akan dimasukkan ke dalam produk yang akan dikembangkan. Selanjutnya, materi dan konsep-konsep ini juga diharapkan dikuasai oleh mahasiswa. Konsep-konsep pada salah satu CP akan dikaitkan dengan konsep-konsep pada CP mata kuliah sehingga kemudian dapat ditentukan materi apa yang akan dimasukkan ke dalam produk yang dikembangkan. Terdapat enam pertimbangan yang yang dilakukan dalam pemilihan materi dua diantaranya adalah relevansi dengan kebutuhan siswa dan lingkungan serta alokasi waktu yang tersedia (Prastowo. 2014).

\section{c. Analisis Kebutuhan}

Analisis kebutuhan dilakukan bertujuan untuk melihat apa saja yang dibutuhkan oleh mahasiswa ketika perkuliahan dilaksanakan. Untuk mengetahui hal tersebut maka yang harus dilakukan di antaranya adalah melakukan tanya jawab baik secara langsung maupun tidak terhadap mahasiswa. Dari hasil analisis kebutuhan ini diharapkan agar produk yang dikembangkan benar-benar sesuai dengan kebutuhan mahasiswa itu sendiri.

\section{d. Analisis Mahasiswa}

Analisis mahasiswa ini dilakukan untuk melihat ciri, kemampuan, dan pengalaman mahasiswa, baik sebagai kelompok maupun individu. Adapun karakteristik yang akan dianalisis meliputi usia, pengetahuan awal, dan tingkat perkembangan kognitif mahasiswa. Kemudian juga dianalasis terkait informasi atau permasalahan tersebut dapat berupa bagaiaman pengetahuan mereka tentang kurikulum, sejauh mana pengetahuan dan pemahaman mereka tentang materi, seperti apa masalah yang terjadi atau dialami dalam pembelajaran, dan harapan mereka dalam kegiatan pembelajaran (Wina. 2008).

\section{Tahap Perancangan (Design)}

Tahap perancangan disebut juga dengan tahap design. Tahap ini bertujuan untuk menemukan cara yang lebih efektif dan efisien dalam mengambangkan suatu rancangan produk yang akan dikembangkan. Rancangan yang dilakukan berdasarkan pada data-data yang diperoleh pada tahap pendefinisian. Tahapan-tahapan yang akan dilakukan pada tahap perancangan ini adalah:

a. Penyusunan Instrumen

Instrumen yang disusun pada penelitian ini terdiri dari instrumen validasi produk. Instrumen validasi produk ini bertujuan untuk menilai kelayakan produk produk yang dikembangkan. Selain menyusun instrumen validasi produk juga terdapat instrument kepraktisan produk yang akan dinilai oleh dosen pengampu mata kuliah. Selain itu juga disusun instrumen tanggapan mahasiswa tentang produk yang telah digunakan. Instrumen ini digunakan sebagai masukan untuk menguji tingkat keefektifan produk yang dikembangkan.

b. Pemilihan Bahan Ajar

Pemilihan Bahan Ajar disesuaiakan dengan kebutuhan dan karakteristik mahasiswa Prodi Pendidikan Fisika UIN Raden Fatah Palembang.

\section{c. Pemilihan Format}

Pemilihan format produk disesuaikan dengan karakteristik mahasiswa dan kebutuhan mahasiswa ketika perkuliahan dilaksanakan.

d. Merancang layout dan story board.

Komponen yang terdapat dalam buku saku (e-media) termodinamika berorientasi android ini secara umum meliputi jenis huruf, bentuk tombol navigasi, dan tata letak gambar di dalam halaman.

\section{Tahap Pengembangan (Development)}

Tahap pengembangan merupakan tahap implementasi dari perencanaan produk yang telah dilakukan pada tahap sebelumnya. Tujuan dari tahap ini adalah untuk 
menghasilkan produk akhir yang layak digunakan. Kegiatan yang dilakukan pada tahap ini adalah melakukan validasi Produk.

Validasi produk dilakukan oleh pakar yang terdiri dari pakar media, materi, dan bahasa. Pada tahap pegembangan produk yang dikembangkan divalidasi oleh pakar dan dosen pengampu mata kuliah untuk mengetahui kelayakan produk yang dikembangkan oleh peneliti sebelum digunakan untuk uji coba lapangan. Hasil validasi dari pakar dan dosen pengampu mata kuliah dijadikan masukan untuk kemudian dilakukan revisi terhadap produk tersebut. Revisi dilakukan supaya produk yang dikembangkan akan lebih baik lagi dengan kritik dan saran yang diberikan oleh pakar dan dosen pengampu mata kuliah.

4. Tahap Penyebaran (Dessiminate)

Tahap ini merupakan tahap terakhir dari penelitian ini. Tahap ini juga disebut sebagai tahap peggunaan perangkat yang telah dikembangkan pada skala yang lebih luas misalnya di kelas lain, di perguruan tinggi lain dengan mata kuliah yang sama, dan oleh dosen yang lain. Namun pada tahap awal penyebaran hanya dilakukan secara terbatas yaitu memberikan produk yang telah dikembangkan kepada dosen dan mahasiswa di Program Studi Pendidikan Fisika UIN Raden Fatah Palembang.

Uji coba lapangan dilakukan pada kelas yang mengambil matakuliah Termodinamika di Program Studi Pendidikan Fisika UIN Raden Fatah Palembang. Adapun tujuan dari kegiatan ini yaitu untuk menentukan apakah produk yang dikembangkan praktis dan efektif jika diterapkan pada kelas Termodinamika dimana mahasiswanya memiliki karakter yang berbeda satu dengan yang lain.

B. Data

Data didefinisikan sebagai keterangan atau bahan nyata yang dapat dijadikan dasar kajian (analisis atau kesimpulan) (Wahyuni. 2008). Jadi dari data yang diperoleh dalam penelitian ini nantinya akan dijadikan dasar untuk menganalisis dan menarik kesimpulan pengembangan buku saku (e-media) termodinamika berorientasi android.

1. Jenis data

Jenis data yag digunakan dalam pengembangan buku saku (e-media) termodinamika berorientasi android ini adalah data kuantitatif. Data kuantitatif diperoleh dari penilaian validasi, angket kepraktisan, dan tes hasil belajar.

2. Sumber data

Sumber data dalam pengembangan buku saku (e-media) termodinamika berorientasi android ini adalah sebagai berikut:

a. Sumber data primer

Data ini ini diperoleh secara langsung dari subyek atau obyek penelitian. Sumber data primer dalam penelitian ini yaitu:

1) Validasi Ahli

Untuk mendapatkan data dan informasi tentang validitas pengembangan buku saku (emedia) termodinamika berorientasi android. Terdapat beberapa penilaian yang dilakukan oleh validator yaitu validasi media, materi, dan bahasa.

2) Dosen

Untuk mendapatkan data dan informasi tentang kepraktisan pengembangan buku saku (e-media) termodinamika berorientasi android.

3) Mahasiswa

Untuk mendapatkan data dan informasi tentang kepraktisan dan efektivitas pengembangan buku saku (e-media) termodinamika berorientasi android.

b. Sumber data skunder

Data ini diperoleh tidak secara langsung dari subyek atau obyek penelitian. Sumber data skunder dalam penelitian ini diperoleh dari $\mathrm{KKNI}$, buku referensi yang dijadikan bahan untuk pengembangan buku saku (e-media) termodinamika berorientasi android.

C. Metode Pengumpulan Data

1. Validasi ahli 
Metode validasi ahli disebut juga dengan penilaian produk oleh pakar untuk menilai baik dari segi isi ataupun spesifikasi pengembangan buku saku (e-media) termodinamika berorientasi android. Validasi ahli yang digunakan dalam penelitian ini adalah validasi ahli media, ahli materi, dan ahli bahasa.

\section{Angket}

Angket yang diberikan kepada dosen dan mahasiswa digunakan untuk mendapatkan data dan informasi tentang tingkat kepraktisan pengembangan buku saku (e-media) termodinamika berorientasi android. Angket ini berisikan seperangkat pertanyaan yang ditujukan kepada responden untuk dijawab. Jenis angket yang digunakan adalah angket tertutup, yaitu angket dengan menyediakan pilihan jawaban untuk dipilih oleh responden penelitian.

\section{Tes}

Tes hasil belajar diberikan kepada mahasiswa digunakan untuk mendapatkan data dan informasi tentang efektivitas pengembangan buku saku (e-media) termodinamika berorientasi android dalam pencapaian hasil belajar dari mahasiswa.

\section{Teknik Analisis Data}

Teknik analisis data hasil validasi produk dan tingkat kepraktisan menggunkan perhitungan data nilai akhir hasil validasi dianalisis dalam skala (0-100) yang kemudian dianalisis dengan menggunakan persamaan persentase hasil dan nilai kategori tingkat validitas dan kategori tingkat kepraktisannya. Data tes hasil belajar mahasiswa dianalisis berdasarkan nilai hasil individual dan klasikal. Secara individu hasil belajar mahasiswa dikategorikan tuntas jika mahasiswa memperoleh nilai yang baik (B). Sedangkan secara klasikal hasil belajar mahasiswa dikategorikan tuntas apabila terdapat $\geq 75 \%$ mahasiswa mencapai nilai baik (B).

\section{HASIL DAN PEMBAHASAN}

A. Hasil Tahap Pendefinisian (Define)

Tahap pendefinisian merupakan tahap pertama yang dilakukan pada penelitian dan pengemabangan ini. Tujuan tahap pendefinisian ini adalah untuk memberikan gambaran akan kebutuhan-kebutuhan apa yang harus dipersiapkan ketika perkuliahan akan dilaksanakan. Terdapat empat kegiatan yang berada pada kegiatan pendefinisian yaitu analisis kurikulum, analisis konsep, analisis kebutuhan, dan analisis mahasiswa.

1. Analisis Kurikulum

Analisis kurikulum dilakukan dengan menelaah kurikulum mata kuliah termodinamika yang terdapat di program studi pendidikan fisika. Program studi pendidikan fisika UIN raden Fatah palembang saat ini sudah menerapkan kurikulum terbaru yaitu KKNI. Pada mata kuliah termodinamika terdapat beberapa capaian pembelajaran yang diaharapkan dimiliki oleh mahasiswa lulusannya. Capaian pembelajaran ini kemudian dikembangkan menjadi lebih khusus seperti capaian pembelajaran mata kuliah, indikator, dan tujuan pembelajaran.

\section{Analisis Konsep}

Tujuan analisis konsep pada penelitian ini adalah untuk menentukan materi yang akan dimasukkan ke dalam produk yang akan dikembang. Dari sekian banyak materi yang terdapat dalam mata kuliah termodinamika dan mempertimbangkan waktu pengembangan produk maka materi yang dipilih dalam produk yang akan dikembangkan pada pengembangan produk ini adalah materi Konsep-konsep dasar termodinamika, Koordinat-koordinat termodinamika, Matematika untuk termodinamika, Sifat-sifat zat murni, Temperatur dan hukum ke nol termodinamika, Sistem dan persamaan keadaan, Usaha mekanik eksternal, Panas dan hukum pertama termodinamika, Hukum kedua termodinamika, Siklus Carnot, entropi, potensial termodinamika, dan Perumusan 
lengkap termodinamika menurut Maxwell. Setiap materi yang telah dipilih kemudian dikelompokkan menjadi satu kesatuan materi yang kemudian disebut dengan bab. Materi tersebut dipilih karena materi ini merupakan materi pokok dan penting bagi mahasiswa untuk dikuasai dan dapat diterapkan dalam kehidupan sehari-hari.

3. Analisis Kebutuhan

Berdasarkan hasil wawancara yang penulis lakukan terhadap dosen pengampu mata kuliah termodinamika dan observasi pada perangkat perkuliahan yang digunakan, menunjukkan bahwa selama ini dosen pengampu hanya menggunakan buku teks sebagai sumber belajar. Dengan kata lain belum memiliki sumber-sumber lain yang digunakan sebagai pelengkap sumber belajar mahasiswa. Selain itu sumber belajar tersebut dalam bentuk buku cetak saja, walaupun ada sebagian mahasiswa yang memiliki sumber dalam bentuk soft copy. Kemudian wawancara kepada mahasiswa didapatkan informasi bahwa mahasiswa membutuhkan bahan ajar yang lebih mudah dibawa.

4. Analisis Mahasiswa

Dari hasil analisis terhadap karakteristik mahasiswa pada program studi Pendidikan Fisika UIN Raden Fatah Palembang diperoleh informasi sebagai beriikut:

a. Mahasiswa fisika yang mengambil mata kuliah termodinamika memiliki usia ratarata di atas 18 tahun.

b. Mahasiswa belum pernah mengambil mata kuliah Termodinamika sebelumnya;

c. Perkembangan kognitifnya apabila ditinjau dari tingkat perkembangan Piaget sudah mencapai tingkat operasi formal yaitu mahasiswa sudah mampu berpikir abstrak sehingga dapat membangun persepsi konsep abstrak yang sama dengan mahasiswa yang lain.

B. Hasil Tahap Perancangan (Design)

Aplikasi yang digunakan dalam

perancangan buku saku (e-media) termodinamika adalah Adobe Flash CS6. Aplikasi ini merupakan aplikasi yang memang dirancang untuk membuat animasi yang kemudian dimanfaatkan untuk membuat aplikasi dalam bentuk pada OS Android (keluaran bentuk .apk). Terdapat beberapa komponen utama dalam mendesain buku saku ini yaitu halaman depan, tentang buku saku, silabus, materi, dan latihan. Hal ini dilakukan karena didasari atas teknik dalam penyusunan buku ajar. Buku saku itu sendiri merupakan bagian dari buku ajar namun lebih praktis dan bisa dimasukkan ke dalam kantong. Selain itu buku saku sendiri juga dikatakan sebagai buku dengan ukuran kecil, ringan, dan bisa disimpan di saku (Arsyad, Azhar. 2011). Buku saku termasuk media cetak, yang mana media cetak merupakan bahan-bahan yang disiapkan untuk pengajaran dan informasi. Adapun bentuk komponen pada buku saku (e-media) berorientasi android ini adalah sebagai berikut.

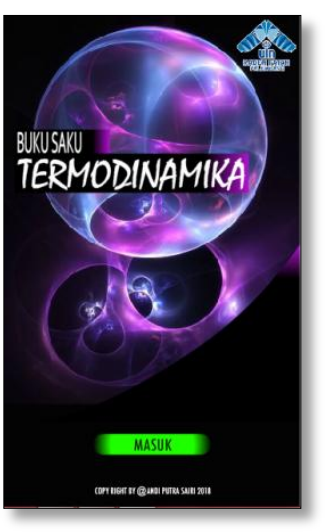

(a)

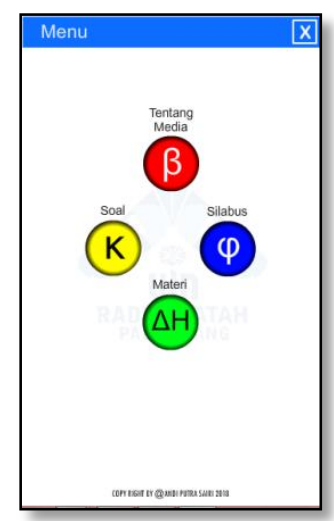

(b) 


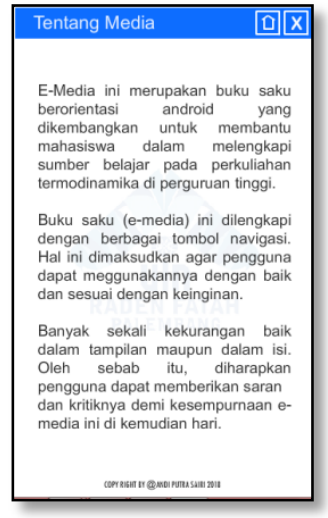

(c)

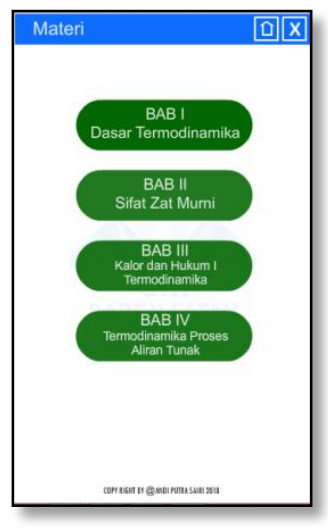

(e)

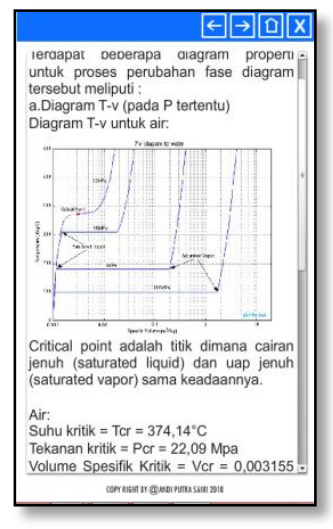

(g)

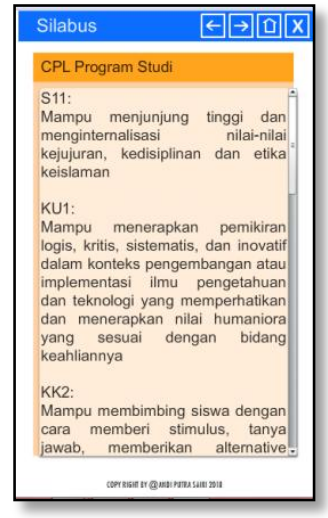

(d)

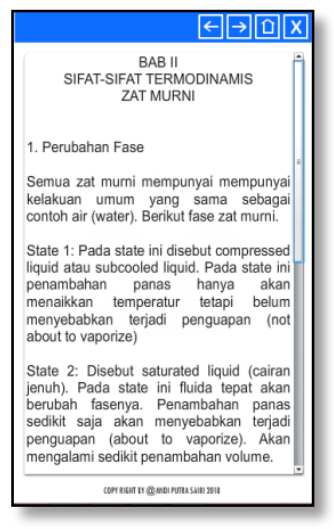

(f)

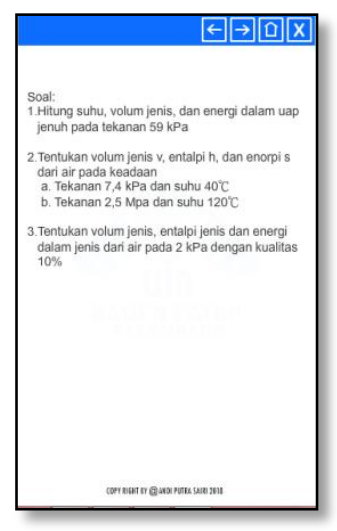

(h)

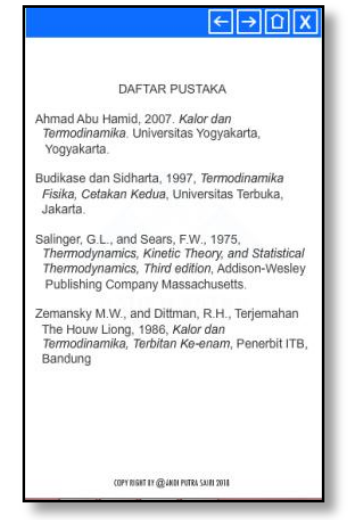

(i)

Gambar 1. Desain Buku Saku (E-Media), (a) Halaman awal, (b) Menu, (c) Tentang buku saku, (d) Silabus, (e) Menu materi, (f) Materi, (g) Gambar, (h) Latihan, (i) Daftar Psutaka

C. Hasil Tahap Pengembangan
(Development)
Data validasi pada penelitian ini menggunakan dua tipe yaitu data kuantitatif dan data kualitatif. Data kuantitatif berupa data dalam bentuk angka-angka yang peneliti dapatkan dari hasil penyebaran lembar angket validasi ke validator. Sedangkan data kualitatif peneliti dapatkan dari saran dan kritik yang diberikan oleh validator dan terdapat pada lembar angket validasi yang telah diberikan. Pakar atau ahli yang menjadi validator terdiri dari 5 orang pakar masing-masing dibagi menjadi 3 orang pakar di bidang media pembelajaran, 2 orang pakar di bidang materi, dan 2 orang pakar di bidang bahasa. Sedangkan penilain tingkat kepraktisan media dilakukan terhadap 2 orang praktisi/dosen mata kuliah termodinamika di UIN Raden Fatah Pelembang.

\section{Validasi Ahli Media}

Terdapat tiga aspek penilain pada angket validasi media yaitua aspek tampilan, penggunaan, dan pemanfaatan. Aspek tampilan terdiri dari 10 butir penilaian dan masing-masing 5 butir penilaian pada aspek 
penggunaan dan pemanfaatan. Hasil validasi media dapat dilihat pada tabel 1 dan gambar 2.

Tabel 1. Hasil Angket Ahli Media

\begin{tabular}{|c|c|c|c|c|}
\hline Aspek & $\begin{array}{l}\text { Total } \\
\text { Skor }\end{array}$ & $\begin{array}{l}\text { Skor } \\
\text { Max }\end{array}$ & $\begin{array}{c}\text { Nilai } \\
\text { Validasi }\end{array}$ & Kategori \\
\hline Tampilan & 37,67 & 40 & 94,17 & SV \\
\hline Penggunaan & 18 & 20 & 90,00 & SV \\
\hline Pemanfaatan & 17,67 & 20 & 88,33 & SV \\
\hline \multicolumn{3}{|c|}{ Nilai Validasi Total } & 272,5 & \\
\hline \multicolumn{3}{|c|}{ Rata-rata } & 90,83 & SV \\
\hline
\end{tabular}

SV= Sangat Valid

Selanjutnya, dari tabel diatas maka didapatkan data dalam bentuk gradik seperti pada gambar 2 .

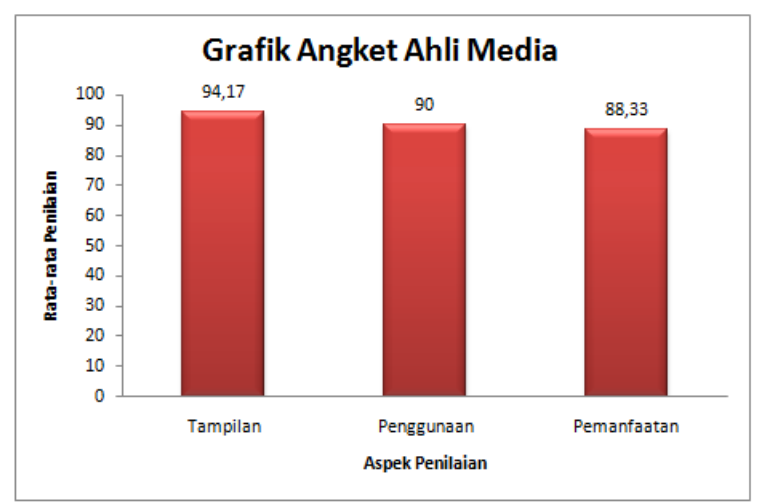

Gambar 2. Hasil Angket Ahli Media

Dari data dan gambar di atas dapat diketahui bahwa aspek tampilan mendapatkan nilai rata-rata tertinggi, sedangkan aspek pemanfaatan mendapatkan skor terendah. Berdasarkan hasil angket validasi media oleh ahli media tersebut dapat disimpulkan bahwa buku saku (e-media) termodinamika berorientasi android berada pada kategori sangat valid dan dapat dilanjutkan pada tahap berikutnya.

2. Validasi Ahli Materi

Aspek yang dinilai dalam angket ahli materi ini terdiri dari aspek pendahuluan, isi, pembelajaran, dan latihan atau evaluasi. Aspek pendahuluan terdiri dari 3 butir penilaian yaitu kejelasan petunjuk belajar, kesesuaian materi media pembelajaran dengan $\mathrm{CP}$, indikator/tujuan pembelajaran, dan keterkaitan materi dengan pembelajaran sebelumnya. Selanjutnya pada aspek isi terdiri dari 4 butir penilaian yang ingin dinilai yaitu keruntutan dan cakupan uraian materi, kejelasan memberikan contoh, kesesuaian dan kemenarikan isi materi, dan penggunaan bahasa yang mudah dipahami. Aspek pembelajran terdiri dari 9 butir penilaian yang akan dinilai yaitu kesesuaian materi dengan karakteristik peserta didik, kejelasan penulisan capaian pembelajara, kesesuaian struktur materi, konsistensi antara tujuan dan tugas pembelajaran, kejelasan uraian materi, ketuntasan materi, kemudahan pemahaman materi, kesesuaian gambar, animasi, video dengan materi, dan tingkat kesulitan materi disesuaikan dengan karakteristik peserta didik. Terdapat 4 butir penilaian yang akan dinilai pada aspek latihan atau evaluasi yaitu kejelasan petunjuk pengerjaan soal atau tes yang disusun, keruntutan latihan sesuai dengan materi, kualitas latihan atau tes dalam media pembelajaran interaktif, dan ketepatan pemberian soal latihan atau tes dan feedback atas jawaban peserta didik. Hasil validasi materi dapat dilihat pada tabel 2 dan gambar 3 .

Tabel 2. Hasil Angket Ahli Materi

\begin{tabular}{|l|c|c|c|c|}
\hline \multicolumn{1}{|c|}{ Aspek } & $\begin{array}{c}\text { Skor } \\
\text { yang } \\
\text { Diperoleh }\end{array}$ & $\begin{array}{c}\text { Skor } \\
\text { Maks }\end{array}$ & $\begin{array}{c}\text { Nilai } \\
\text { Validasi } \\
(\%)\end{array}$ & Kategori \\
\hline $\begin{array}{l}\text { Pendahu- } \\
\text { luan }\end{array}$ & 11,5 & 12 & 95,83 & SV \\
\hline Isi & 15 & 16 & 93,75 & SV \\
\hline $\begin{array}{l}\text { Pembela- } \\
\text { jaran }\end{array}$ & 33 & 36 & 91,67 & SV \\
\hline $\begin{array}{l}\text { Latihan } \\
\text { atau } \\
\text { evaluasi }\end{array}$ & 15 & 16 & 93,75 & SV \\
\hline \multicolumn{2}{l|}{ Nilai Validasi Total } & & 375,00 & SV \\
\hline \multicolumn{2}{l|}{ Rata-rata }
\end{tabular}

Keterangan: SV= Sangat Valid 
Selanjutnya, dari tabel diatas maka didapatkan data dalam bentuk gradik seperti pada gambar 3 .

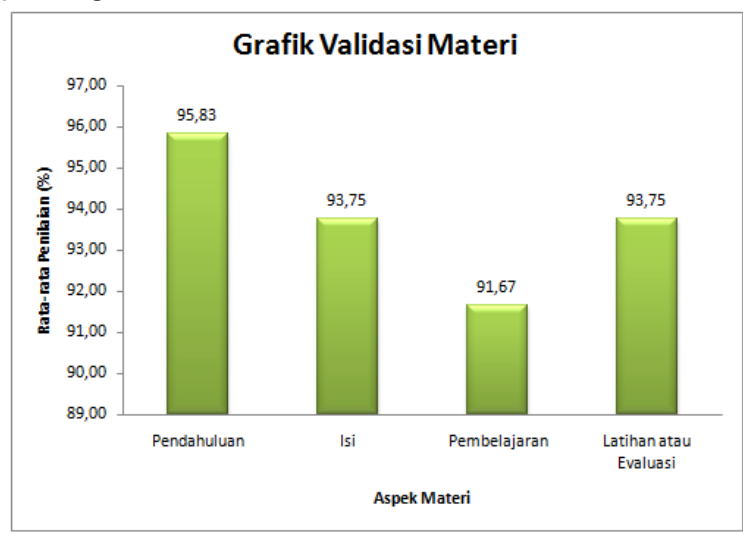

Gambar 3. Hasil Angket Ahli Materi

Data tentang validasi oleh ahli materi tersebut dapat diketahui bahwa aspek pendahuuan mendapatkan rata-rata skor tertingi, sedangkan aspek pembelajaran mendapatkan skor terendah. Berdasarkan data ini dapat disimpulkan bahwa secara keseluruhan validasi materi dalam pengembangan buku saku (e-media) termodinamika berorientasi android berada pada kategori sangat valid dan dapat dilanjutkan kepada tahap berikutnya.

\section{Validasi Ahli Bahasa}

Validasi selanjutnya terhadap buku saku (e-media) termodinamika berorientasi android yaitu validasi bahasa oleh ahli bahasa yang dilakukan untuk mengetahui kesesuaian bahasa yang digunakan dalam buku saku (emedia) termodinamika berorientasi android dilihat dari tata tulis dan ejaan dalam bahasa Indonesia yang benar. Validator selaku ahli bahasa dalam penelitian ini dilakukan oleh 2 orang ahli bahasa.

Terdapat 6 aspek yang dinilai dalam angket ahli bahasa ini yaitu aspek kesesuaian bahasa dengan perkembangan mahasiswa, komunikatif, dialogis dan interaktif, koherensi dan keruntutan alur pikir, kesesuaian dengan kaidah bahasa Indonesia yang benar, dan penggunaan istilah dengan simbol atau lambang. Masing-masing aspek memiliki dua butir penilaian yang akan dinilai yaitu kesesuaian dengan tingkat perkembangan mahasiswa dan kesesuaian dengan tingkat perkembangan emosional mahasiswa pada aspek kesesuaian bahasa dengan perkembangan mahasiswa. Butir keterpahaman mahasiswa terhadap pesan dan kesesuaian ilustrasi dengan substansi pesan pada aspek komunikatif. Butir kemampuan mahasiswa untuk merespon pesan dan dorongan berpikir kritis pada mahasiswa pada aspek dialogis dan interaktif. Butir ketertautan antar bab dan antar bab dengan sub bab dan keutuhan makna dalam bab dan dalam sub bab pada aspek koherensi dan keruntutan alur pikir. Kemudian butir ketepatan tata bahasa dan ketepatan ejaan pada aspek kesesuaian dengan kaidah bahasa Indonesia yang benar. Buitr konsistensi penggunaan istilah dan konsistensi penggunaan simbol atau lambang pada aspek penggunaan istilah dengan simbol atau lambang. Hasil validasi bahasa dapat dilihat pada tabel 3 dan gambar 4 .

Tabel 3. Hasil Angket Ahli Bahasa

\begin{tabular}{|l|c|c|c|c|}
\hline \multicolumn{1}{|c|}{ Aspek } & $\begin{array}{c}\text { Skor } \\
\text { Total }\end{array}$ & $\begin{array}{c}\text { Skor } \\
\text { Maks. }\end{array}$ & $\begin{array}{c}\text { Nilai } \\
\text { Validasi } \\
\text { (\%) }\end{array}$ & $\begin{array}{c}\text { Kate- } \\
\text { gori }\end{array}$ \\
\hline $\begin{array}{l}\text { Kesesuaian } \\
\text { bahasa dengan } \\
\text { perkembangan } \\
\text { mahasiswa }\end{array}$ & 7,5 & 8 & 93,75 & SV \\
\hline $\begin{array}{l}\text { Komunikatif } \\
\text { Dialogis dan } \\
\text { interaktif }\end{array}$ & 7,5 & 8 & 93,75 & SV \\
\hline $\begin{array}{l}\text { Koherensi dan } \\
\text { keruntutan alur } \\
\text { pikir }\end{array}$ & 7,5 & 8 & 87,5 & SV \\
\hline $\begin{array}{l}\text { Kesesuaian } \\
\text { dengan kaidah } \\
\text { bahasa } \\
\text { Indonesia yang } \\
\text { benar }\end{array}$ & 8 & 8 & 100 & SV \\
\hline $\begin{array}{l}\text { Penggunaan } \\
\text { istilah dengan } \\
\text { simbol atau } \\
\text { lambang }\end{array}$ & 8 & 8 & 100 & SV \\
\hline $\begin{array}{l}\text { Nilai Validasi Total } \\
\text { Rata-rata }\end{array}$ & & & 94,79 & SV \\
\hline
\end{tabular}


Keterangan: SV= Sangat Vali

Selanjutnya, dari tabel diatas maka didapatkan data dalam bentuk grafik seperti pada gambar 4 .

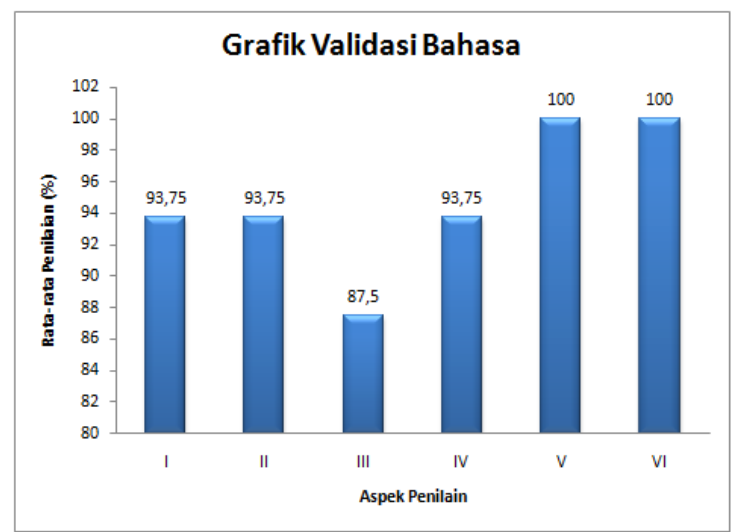

Gambar 4. Hasil Angket Ahli Bahasa

Data tentang validasi oleh ahli bahasa tersebut menunjukkan bahwa terdapat dua aspek yang mendapatkan nilai tertinggi yaitu aspek kesesuaian dengan kaidah bahasa Indonesia yang benar dan aspek penggunaan istilah dengan simbol atau lambang, sedangkan aspek dialogis dan interaktif mendapatkan skor terendah. Berdasarkan data ini dapat disimpulkan bahwa secara keseluruhan validasi bahasa dalam pengembangan buku saku (e-media) termodinamika berorientasi android berada pada kategori sangat valid dan dapat dilanjutkan kepada tahap berikutnya.

Data tingkat validasi oleh ahli media, materi, dan bahasa di atas kemdian dianamisis untuk menghitung nilai rata-rata validasi dari ketiga aspek penilaian tersebut. Data nilai ratarata validasi buku saku (e-media) termodinamika berorientasi android dapat dilihat pada tabel 4 .

Tabel 4. Validasi Buku Saku (E-Media)

Termodinamika Berorientasi Android

\begin{tabular}{|l|c|c|}
\hline \multicolumn{1}{|c|}{$\begin{array}{c}\text { Validasi } \\
\text { Ahli }\end{array}$} & Nilai (\%) & Kategori \\
\hline Media & 90,83 & Sangat Valid \\
\hline Materi & 93,75 & Sangat Valid \\
\hline Bahasa & 94,79 & Sangat Valid \\
\hline
\end{tabular}

\begin{tabular}{|l|c|l|} 
Total & 279,37 & \\
\hline Rata-rata & 93,12 & Sangat Valid \\
\hline
\end{tabular}

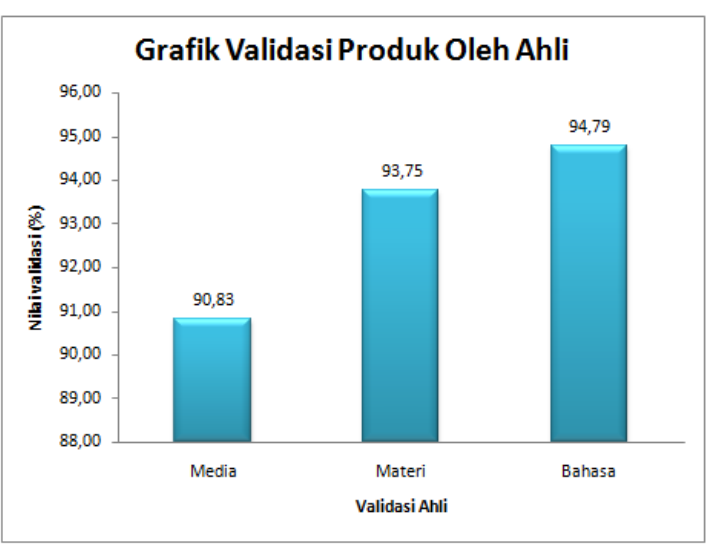

Gambar 5. Grafik Validasi Oleh Ahli

Dari data diatas dapat dijelaskan bahwa aspek bahasa memiliki nilai validasi tertinggi yaitu sebesar $94,79 \%$ dan nilai validasi oleh ahli media mendapatkan nilai paling rendah yaitu sebesar 90,83\%. Adapun rata-rata nilai validasi dari tiga nilai validasi oleh ahli tersebut adalah sebesar 93,12\%. Nilai ini jika didasarkan pada tabel tingkat validitas suatu produk masuk ke dalam ketegori sangat valid. Dengan demikian buku saku (e-media) termodinamika berorientasi android layak dilakukan uji coba pada tahap selanjutnya.

D. Hasil Tahap Penyebaran (Dessiminate)

1. Respon Dosen

Uji kepraktisan responden dosen terhadap buku saku (e-media) termodinamika berorientasi android dilakukan dengan memberikan instrumen angket. Angket responden dosen di berikan kepada dosen pengampu mata kuliah termodinamika. Pemberian angket dilakukan setelah dosen menggunakan buku saku (e-media) termodinamika berorientasi android. Hasil angket tersebut dapat dilihat pada tabel 5 gambar 6 .

Tabel 5. Hasil Angket Respon Dosen

\begin{tabular}{|c|c|c|c|c|}
\hline Aspek & Skor & $\begin{array}{c}\text { Skor } \\
\text { Maks }\end{array}$ & $\begin{array}{c}\text { Nilai } \\
\text { Validasi } \\
(\%)\end{array}$ & Kategori \\
\hline
\end{tabular}




\begin{tabular}{|l|c|c|c|c|} 
Pembelajaran & 39,00 & 44 & 88,64 & SP \\
\hline Tampilan & 22,00 & 24 & 91,67 & SP \\
\hline Pemograman & 11,00 & 12 & 91,67 & SP \\
\hline \multicolumn{2}{|c|}{ Nilai Validasi Total } & $\mathbf{2 7 1 , 9 7}$ & \\
\hline \multicolumn{2}{|c|}{ Rata-rata } & $\mathbf{9 0 , 6 6}$ & SP \\
\hline
\end{tabular}

${ }^{*}$ SP: Sangat Praktis

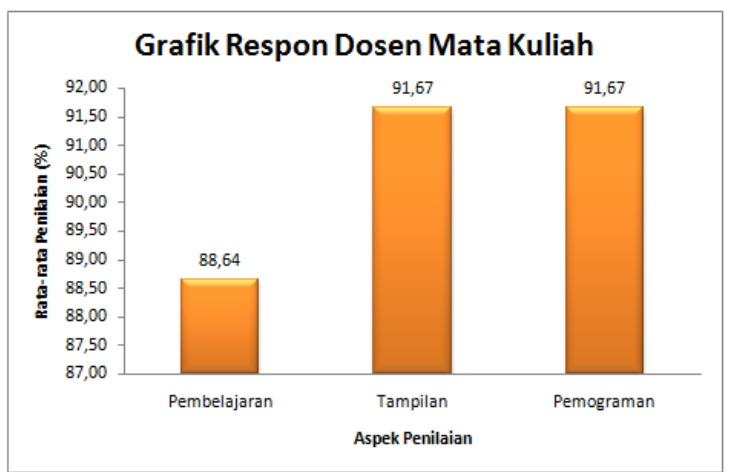

Gambar 6. Hasil Angket Respon Dosen

Data di atas juga menggambrkan dimana terdapat dua aspek yang memiliki nilai tertinggi yaitu aspek tampilan dan pemograman. Sedangkan aspek pembelajaran mendapatkan skor terendah. Berdasarkan hasil angket respon guru tersebut dapat disimpulkan bahwa buku saku (e-media) termodinamika berorientasi android sangat praktis.

2. Respon Mahasiswa

Angket responden mahasiswa ini diberikan kepada mahasiwa pendidikan fisika UIN Raden Fatah Palembang yang berjumlah 16 peserta didik. Angket tersebut diberikan setelah mahasiswa mengikuti perkuliahan menggunakan buku saku (e-media) termodinamika berorientasi android yang telah dikembangkan. Hasil angket tersebut dapat dilihat pada tabel 6 dan gambar 7 .

Tabel 6. Hasil Angket Responden Mahasiswa

\begin{tabular}{|l|c|c|}
\hline \multicolumn{1}{|c|}{ Aspek } & $\begin{array}{c}\text { Nilai } \\
\text { Kepraktisan } \\
\text { (\%) }\end{array}$ & Kategori \\
\hline Pembelajaran & 100,00 & SP \\
\hline Tampilan & 73,33 & P \\
\hline
\end{tabular}

\begin{tabular}{|c|c|c|}
\hline Pemograman & 93,33 & SP \\
\hline Nilai Validasi Total & $\mathbf{2 6 6 , 6 7}$ & \\
\hline Rata-rata & $\mathbf{8 8 , 8 9}$ & SP \\
\hline
\end{tabular}

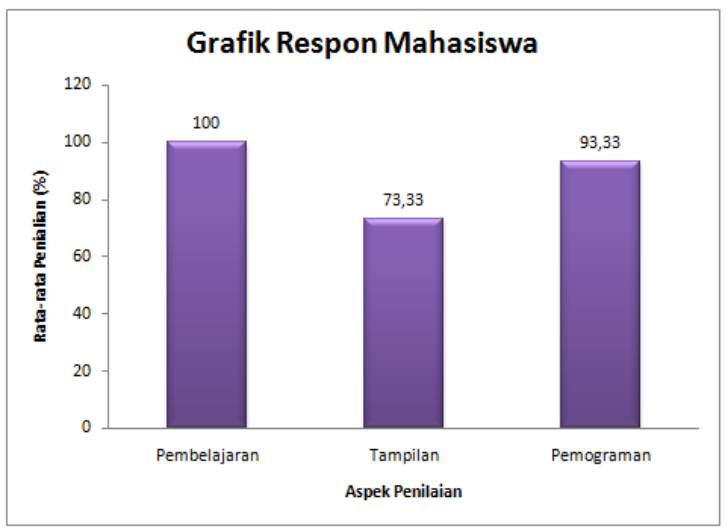

Gambar 7. Hasil Angket Respon Mahasiwa

Dari data tersebut dapat diketahui bahwa aspek pembelajaran mendapatkan ratarata skor tertinggi, sedangkan aspek tampilan mendapatkan skor terendah. Berdasarkan hasil angket respon mahasiswa tersebut dapat disimpulkan bahwa buku saku (e-media) termodinamika berorientasi android sangat praktis. Nilai hasil respon peserta didik terhadap media pembelajaran berupa buletin IPA terpadu dalam bentuk buku saku pada materi bunyidengan persentase $80 \%$ dengan kriteria layak (Asyhari, Ardian. Dan Silvia, Helda. 2017). Dengan demikian bisa dinyatakan bahwa buku saku baik bentuk cetak maupun elektrtonik memiliki respon yang baik oleh pengguna dan layak untuk dijadikan bahan ajar.

3. Hasil Tes

Uji efektifitas buku saku (e-media) termodinamika berorientasi android dilaksanakan dengan memberikan instrumen tes kepada mahasiswa setelah mengikuti perkuliahan dengan menggunakan buku saku (e-media) termodinamika berorientasi android yang dikembangkan. Tujuan uji efektifitas terhadap produk yang dikembangkan adalah untuk mengetahui hasil belajar mahasiswa 
setelah mengikuti pembelajaran dengan menggunakan buku saku (e-media) termodinamika berorientasi android. Sebanyak 16 orang mahasiswa hadir dalam kegiartan tes yang dilaksanakan di kelas. Hasil belajar mahasiswa yang dimaksud meliputi aspek pengetahuan. Hasil belajar mahasiswa tersebut dapat dilihat pada tabel 7 dan gambar 8.

Tabel 7. Hasil Belajar Mahasiswa

\begin{tabular}{|c|c|c|}
\hline $\begin{array}{c}\text { Nomor } \\
\text { Mahasiswa }\end{array}$ & Nilai & Keterangan \\
\hline 1 & 75 & Tuntas \\
\hline 2 & 80 & Tuntas \\
\hline 3 & 80 & Tuntas \\
\hline 4 & 75 & Tuntas \\
\hline 5 & 86 & Tuntas \\
\hline 6 & 75 & Tuntas \\
\hline 7 & 65 & Belum Tuntas \\
\hline 8 & 75 & Tuntas \\
\hline 9 & 65 & Belum Tuntas \\
\hline 10 & 75 & Tuntas \\
\hline 11 & 84 & Tuntas \\
\hline 12 & 78 & Tuntas \\
\hline 13 & 80 & Tuntas \\
\hline 14 & 75 & Tuntas \\
\hline 15 & 65 & Belum Tuntas \\
\hline 16 & 75 & Tuntas \\
\hline Jumlah & $\mathbf{1 2 0 8}$ & $\mathbf{1 3}$ \\
\hline Rata-rata & $\mathbf{7 5 , 5}$ & $\mathbf{8 1 , 2 5 \%}$ \\
\hline
\end{tabular}

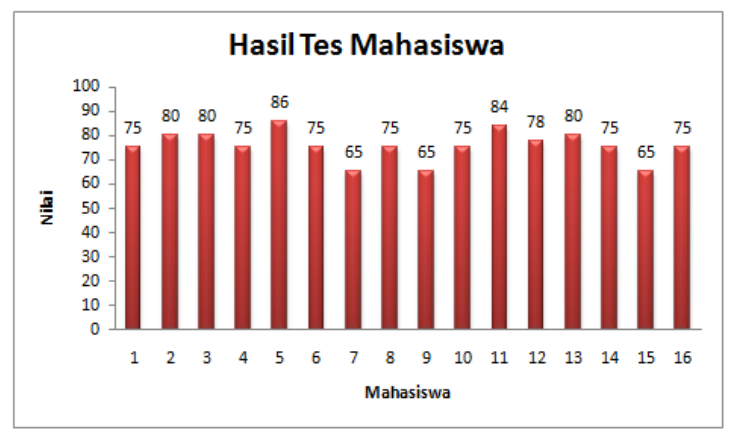

Gambar 8. Hasil Belajar Mahasiswa

Berdasarkan data dari hasil tes yang diperoleh mahasiswa dapat dijelaskan dimana data nilai secara klasikal nilai aspek pengathuan mahasiswa mendapatkan rata-rata nilai 75,5 dengan kategori baik. Dari aspek penilaian ini nilai tertinggi sebesar 86 dan nilai terendah sebesar 65 .
Dari data yang diperoleh dapat diketahui bahwa ketuntasan belajar secara klasikal dapat tercapai secara maksimal. Hal tersebut ditunjukkan dengan jumlah mahasiswa yang tuntas dalam belajar. Sebanyak 13 orang mahasiswa telah tuntas dalam belajar atau sebesar $81,25 \%$ ketuntasan secara klasikal. Berdasarkan pencapaian data ini, maka dapat disimpulkan bahwa buku saku (e-media) termodinamika berorientasi android sangat efektif dalam mencapai hasil belajar mahasiswa.

\section{KESIMPULAN}

Berdasarkan pengembangan dan uji coba yang telah dilakukan terhadap buku saku (e-media) termodinamika berorientasi android, diperoleh kesimpulan sebagai berikut.

1. Pengembangan produk dilakukan dengan melalui beberapa tahap yaitu pendefinisian, perancangan, pengembangan, dan penyebaran. Pada tahap pendefinisian di peroleh dari hasil analisis kurikulum, analisis konsep, analisis kebutuhan, dan analisis mahasiswa. Dari kegiatan pendefinisian ini ditetapkan buku saku (emedia) termodinamika berorientasi android sebagai bahan ajar yang akan dikembangkan dan dilanjutkan ke tahap perancangan (desain) produk. Tahap perancangan ini dilakukan sesuai dengan kaidah dan strukutr dari buku ajar namun diorientaikan kesistem android. buku saku (e-media) termodinamika berorientasi android ini terdiri dari halaman utama, halaman menu yang menggantikan halam daftar isi pada buku, halaman materi, dan halaman daftar pustaka.

2. Hasil tahap pengembangan diperoleh dari nilai validitas, kepraktisan, dan efektifitas produk. Validitas buku saku (e-media) termodinamika berorientasi android yang dinilai oleh ahli/pakar media, materi, dan kebahasaan. Validasi oleh ahli media menunjukkan bahwa buku saku (e-media) 
termodinamika berorientasi android sangat valid dengan rata-rata nilai $90,83 \%$. Validasi oleh ahli materi juga menunjukkan bahwa buku saku (e-media) termodinamika berorientasi android sangat valid dengan rata-rata nilai $93,75 \%$. Kemudian nilai validasi oleh ahli bahasa menunjukkan bahwa buku saku (e-media) termodinamika berorientasi android sangat valid dengan rata-rata nilai $94,79 \%$. Dari ketiga nilai validasi oleh ahli ini menyatakan bahwa buku saku (e-media) termodinamika berorientasi android sangat valid dengan nilai rata-rata validasi sebesar $93,12 \%$.

3. Buku saku (e-media) termodinamika berorientasi android efektif digunakan sebagai bahan ajar pada mata kuliah Termodinamika di perguruan tinggi karena berdasarkan uji coba produk didapatkan nilai efektivitasnya sebesar $81,25 \%$ dan nilai rata-rata mahasiswa 75,5.

Dari kesimpulan yang telah disampaikan, penulis menyarankan supaya dalam menerapkan buku saku (e-media) termodinamika berorientasi android ini hendaknya dosen memperbolehkan mahasiswa menggunakan smartphone saat kegiatan perkuliahan dilaksanakan karena produk yang dikembangkan menggunakan aplikasi yang hanya bisa dibuka di smartphone dengan OS Android. Kemudian dosen hendaknya mempertimbangkan alokasi waktu dalam kegiatan perkuliahan supaya setiap kegiatan yang telah dibuat dan direncakan dapat terlaksana dengan baik. Selain itu, peneliti lanjutan diharapkan dapat melakukan pengembangan produk pada materi atau bahkan pada mata kuliah yang berbeda untuk memperoleh hasil yang baik lagi. Selain itu dapat dijadikan pilihan lain dalam memilih bahan ajar di masa yang akan datang.

\section{DAFTAR PUSTAKA}

Adnan, M. 2009. Penelitian pengembangan. Malang: Universitas Negeri Malang.

Arsyad, Azhar. (2011). Media Pembelajaran. Jakarta: PT Raja Grafindo Persada.

Asyhari, Ardian. Dan Silvia, Helda. (2017). Pengembangan Media Pembelajaran Berupa Buletin dalam Bentuk Buku Saku untuk Pembelajran IPA Terpadu. Jurnal IImiah Pendidikan Fisisika (JIPF) Al-Biruni. Volume $5 . \quad$ No.1. DOI: http://dx.doi.org/10.24042/jpifalbiruni.v5i1. 100

Prastowo, Andi. (2014) Pengembangan Bahan Ajar Tematik Tinjauan Teoretis dan Praktik. Jakarta: Kencana.

Sanjaya, Wina. (2008). Perencanaan dan Desain Sistem Pembelajaran. Jakarta: Prenadamedia Group.

Sugiyono. (2010). Metode Penelitian Pendidikan Pendekatan Kuantitatif, Kualitatif, dan R\&D. Bandung: Alfabeta.

Trianto. (2009). Mendesain Model Pembelajaran Inovasi Progresif. Jakarta: Kencana Prenada Media.

Wahidmurni. (2008). Peneitian Tindakan Kelas dan Teori Menuju Praktik. Malang: UM Press.

Yaqin, Ainul. (2017). Pengembangan Buku Saku Digital Berbasis Android Sebagai Pendukung Bahan Ajar Pada Materi Pph Pasal 21. Jurnal Pendidikan Akuntansi (JPAK). Volume 5. No.1. 